\title{
Glyceryn-Jelly as mounting medium for permanent slides for protists and rotifers: a proposal for didactic purposes
}

\author{
Marcio Borba da Silva ${ }^{1 *}$ \\ Caique dos Santos Aguiar ${ }^{1}$ \\ Cínthya Viana Souza Rocha ${ }^{1}$ \\ Sara Barbosa Santos ${ }^{1}$ \\ Matheus Santos dos Anjos ${ }^{1}$ \\ Rafael Sampaio Vieira Silva ${ }^{1}$ \\ Patrícia Belini Nishiyama ${ }^{1}$ \\ Ricardo Evangelista Fraga ${ }^{1}$ \\ Mariane Amorim Rocha ${ }^{1}$ \\ Paulino Pereira Oliveira ${ }^{2}$ \\ ${ }^{1}$ Universidade Federal da Bahia, Campus Anísio Teixeira \\ Instituto Multidisciplinar em Saúde, Laboratório de Zoologia \\ Rua Hormindos Barros 58, Quadra 17, Lote 58, CEP 45.029-094, Vitória da Conquista - BA, Brasil \\ ${ }^{2}$ Universidade Estadual de Feira de Santana, Departamento de Ciências Biológicas \\ Laboratório de Micromorfologia Vegetal \\ Avenida Transnordestina s/n, Novo Horizonte, CEP 44.036-900 Feira de Santana - BA, Brasil \\ * Autor para correspondência \\ biolmarcioborba@gmail.com
}

Submetido em 02/07/2020

Aceito para publicação em 08/09/2020

\section{Resumo}

Gelatina glicerinada como meio de montagem de lâminas permanentes de protistas e rotíferos: uma proposta para fins didáticos. A proposta deste estudo é estabelecer um protocolo de preparo de lâminas permanentes de protistas e rotíferos através da adaptação da técnica de gelatina glicerinada de Kisser, composta por três etapas. Um total de 450 lâminas de protistas e rotíferos foram confeccionadas. Após um período de dois anos, as lâminas permaneceram estáveis, sem sinais de contaminação por fungos e os organismos mantiveram sua conformação morfológica íntegra. Técnica proposta é promissora quanto a conservação das características morfológicas dos espécimes, apresentando baixo risco de manipulação, baixo custo, poucos reagentes e fácil manuseio, permitindo a construção de um acervo didático para aulas práticas.

Palavras-chave: Ensino de biologia; Laminário; Microorganismos; Microscopia; Verniz vitral 


\section{Abstract}

The proposal of this study is a protocol for the preparation of permanent sheets of protists and rotifers by adapting a Kisser glyceryn-jelly technique in three stages. A total of 450 sheets of protists and rotifers were made. After a period of 2 years, the slides remained stable, with no signs of fungal contamination and the organisms maintained their integral morphological conformation. The proposed technique is promising for the conservation of the morphological characteristics of the specimens, presenting low risk of manipulation, low cost, few reagents and easy handling, allowing the creation of a didactic collection for practical classes.

Key words: Biology teaching; Laminary; Microorganisms; Microscopy; Varnish vitral

Teaching about microorganisms such as protozoa, microalgae and micrometazoans is difficult, since, in most cases, there is no approximation to the object of study, and the focus tends essentially towards theoretical learning. Thus, the preparation of slides with these groups is essential for students to have close experience with this micromorphological universe thus ensuring learning.

Numerous attempts to prepare protists slides have been carried out with the aim of properly arranging these organisms in a preserved slide collection. Among these, the silver proteinate impregnation technique (protargol) proposed by Dieckmann (1995) and its adaptation by Silva-Neto (2000) stand out. This method was initially developed for use in ciliated protists, especially in taxonomic studies. It is a technique that requires a considerable number of steps and reagents; it is used exclusively for ciliated protists; and the organisms prepared by protargol do not always maintain their morphological integrity, thus their viability is reduced. Nevertheless, there is no technique in the literature for teaching purposes that involves protists and rotifers, which are abundant representatives of freshwater plankton samples. Therefore, we tested the slide mounting technique in Kisser glyceryn-jelly according to SalgadoLabouriau (1961), widely used in palynological studies.

For Rotifera, permanent slide protocols have also been established, including the one recently proposed by Jersabeck et al. (2010) using Norland 61 (NOA 61) optical adhesive, a liquid photopolymer mounted in pure glycerin, a promising technique for the construction of permanent slides for scientific purposes, and recently applied to the creation of the Rotifera collection in Ulaanbaatar, Mongolia.
In the present study, the use of Kisser glyceryn-jelly (SALGADO-LABOURIAU, 1961) for the mounting of permanent slides for didactic purposes included the following taxonomic groups: amoeboid protists (Amoeba sp., Difflugia sp., Quadrulella sp. snd cysts Entamoeba sp.), ciliated protists (Euplotes sp., Paramecium sp. and Vorticella sp.), flagellate protists (Euglena sp., Phacus sp., Peridinium sp., Trachelomonas sp.), diverse microalgae (Anabaena sp. and Pediastrum sp.) and rotifers (Brachionus sp., Lecane sp. and Plationus sp.). These organisms were set with different fixers: (i) Formaldehyde at $4 \%$ final concentration buffered with borax for ameboid protists and flagellate, and rotifer; (ii) Transeau for microalgae and (iii) Mercury Chloride for ciliate.

The preparation of glyceryn-jelly follows what is proposed by Kisser (SALGADO-LABOURIAU, 1961), with only one adaptation: replacing phenol with thymol. For this preparation, $50 \mathrm{~g}$ of colorless gelatin in sheet were weighed and immersed in $175 \mathrm{~mL}$ of distilled water for $1 \mathrm{~h}$. Then the mixture was taken to the water bath $\left(40^{\circ} \mathrm{C}\right)$ and shaken gently with a glass stick. Soon after, $150 \mathrm{~mL}$ of glycerin (100\%) was added, mixing until complete homogenization was reached. Subsequently, $7 \mathrm{~g}$ of phenol crystals (or about 5 drops), or $2 \mathrm{~g}$ of thymol, were added to prevent the development of microorganisms in the medium (Figure $1 \mathrm{~A}$ ). While still heated, the medium was distributed in glass containers with a wide mouth and a lid, like a petri dish, in a not too thick layer (ca.5 $\sim \mathrm{mm}$ ), remaining uncovered until cool. The mixture solidified upon cooling and the air bubbles rose to the surface (a part that must be discarded when assembling the slide) (Figure 1B). The plates were wrapped in film paper and stored under refrigeration at 
FIGURE 1: Stages for preparing permanent slides using glyceryn-jelly. A: Preparation of glyceryn-jelly in a water bath; B: Glyceryn-jelly packed in a petri dish; C: Organisms isolated in microtubes and immersed in glycerol; D: Metal rim used to stamp the blade with paraffin (bar: $5 \mathrm{~mm}$ ); E: Immersion of the metal rim in the melted paraffin with the aid of the heating plate; F: Paraffin stamp on the blade using the metal rim; G: Paraffin ring marked on the slide; H: Cutting glyceryn-jelly and depositing it on the slide; I: Heating of the slide and subsequent addition of organisms immersed in glycerol; J: Deposition of the coverslip on the slide; K: Sealing with 3 layers of varnish vitral about $0.2 \mathrm{~cm}$ from the edge of the coverslip and L: Schema of the slide mounted by this technique.
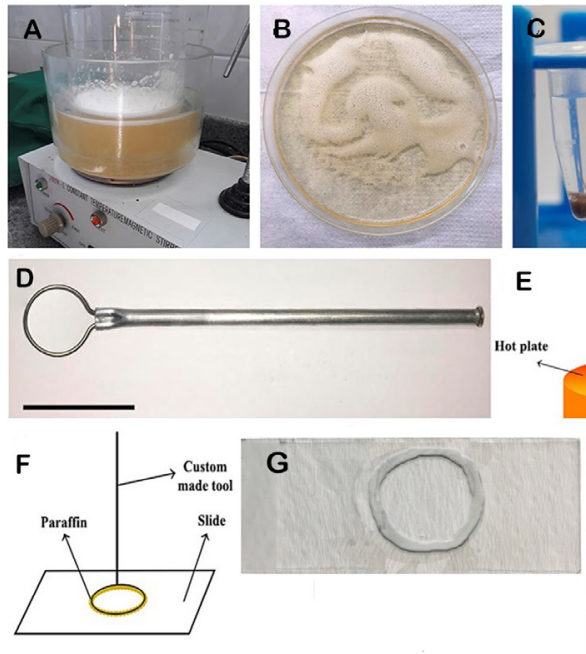

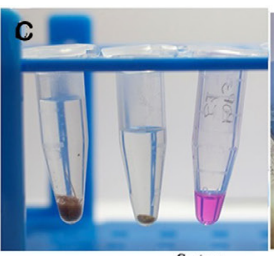

$\mathrm{E}$

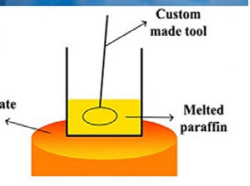

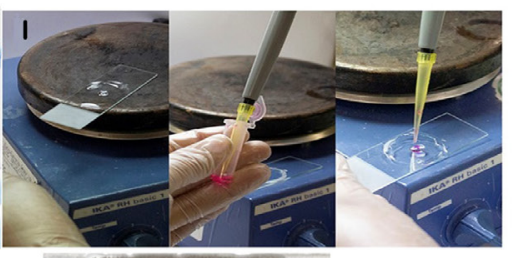

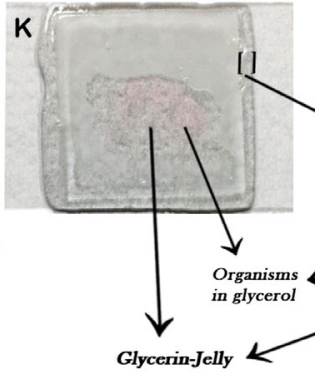

L

Glycerin-Jelly

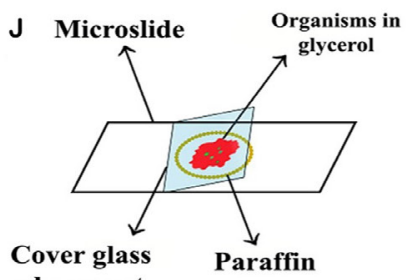

placement

Paraffin

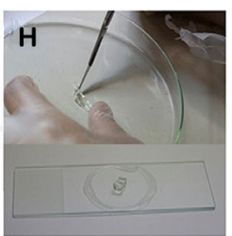

Paraffin frame

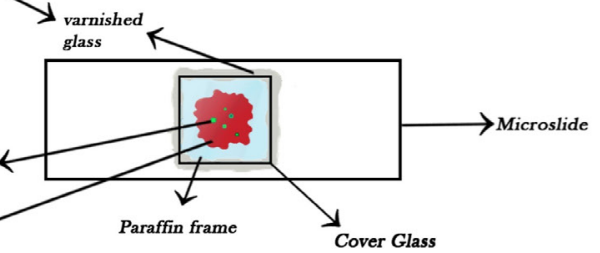

$-4^{\circ} \mathrm{C}$. This mounting medium was used in the technique proposed here, consisting of three stages (Figure 1).

\section{Stage (1): Isolation, transfer and impregnation of organisms in glycerol}

1. The organisms from the fixed samples (as recommended above) were observed in a Sedgwick Rafter-type chamber under an optical microscope, pipetted, with the aid of a $20 \mu$ volume single-channel micropipette, deposited in $1.5 \mathrm{~mL}$ microtubes (eppendorf type, U-shaped bottom) and properly identified. Subsequently, the specimens were stained according to need: (i) rose bengal for ciliated protists, amoeboid protists and rotifer; and (ii) lugol for cysts of parasitic ameboid protists, such as Entamoeba sp. Other organisms were not stained, such as photosynthetic forms.

2. A period of $48 \mathrm{~h}$ was allowed for the organisms to settle in the microtube.

3. Finally, the supernatant was removed with the aid of micropipettes and $1.2 \mathrm{~mL}$ of glycerin was added to the microtube (Figure 1C). After that, the microtubes were taken to the oven at $50^{\circ} \mathrm{C}$ for $24 \mathrm{~h}$ for the water to evaporate and to promote a gradual change in the organisms embedded in the fixer to glycerol, the suspension thus acquiring a gelatinous aspect.

The intention of using the glycerin mentioned was to promote the gradual change from the organisms embedded in the fixative to this more gelatinous medium, thus promoting better results when they are incorporated into the assembly medium (glycerin-jelly).

\section{Stage (2): Mounting of organisms in Kisser glyceryn-jelly}

4. A metal rim (diameter $20 \mathrm{~mm}$ ) (Figure $1 \mathrm{D}$ ) was immersed in the melted histological paraffin (Figure 1 E) and placed on the slide for printing the paraffin (like a stamp when applied to a sheet of paper) (Figure $1 \mathrm{~F}$ and $1 \mathrm{G})$.

5. With the paraffin circle outlined on the slide, solid glyceryn-jelly (cut into $3 \mathrm{~mm}$ cubes) was added over the glass slide (Figure $1 \mathrm{H}$ ) and taken to a hot plate under 
a temperature of $60^{\circ} \mathrm{C}$ to promote the melting of the gelatin until it became gelatinous (Figure 1I). Maximum attention was needed during this step, especially in relation to the temperature of the hot plate, to prevent the formation of bubbles at the highest temperature.

6. Subsequently, an aliquot of the glycerol containing the organisms was added onto the melted gelatin arranged under the slide, using a $0.20 \mu 1$ monochannel micropipette (Figure 1I). The glycerin gelatin was gently homogenized with the organism impregnated with glycerol with the aid of a pointed stylus.

\section{Stage (3): Slides sealing and storage}

7. The next step was to cover this with the coverslip (Figure 1J). An interval of time was needed for the solidification of the mounting medium and the paraffin that works as a sealant.

8. The slide was taken under an optical microscope to check the quality of the preparation; then it was sealed with 3 layers of varnish vitral about $0.2 \mathrm{~cm}$ from the edge of the coverslip (Figure 1K and 1L).

9. Finally, the slide was stored horizontally in a slide holder box in a climatized environment with an average temperature of $20^{\circ} \mathrm{C}$.

A total of 450 slides were made using this technique (Figure 1). Preparation was quick, taking around one to two minutes to assemble each slide (stages 2 and 3). The slides remained stable: the first ones were made more than two years ago and showed no signs of degradation. The technique preserved the color of the organisms, except those treated with lugol which became discolored due to its photosensitivity - these should therefore be used in temporary slides; it also maintained the visibility of the morphological characteristics (nucleus, cilia, flagella, pseudopods, corona, chloroplasts) (Figure 2). It presented a short drying period and had a low preparation cost (on average $\mathrm{R} \$ 21.30$ per $100 \mathrm{~mL}$ of the mounting medium, with a yield of about 130 slides) when compared to other techniques that use Entellan ${ }^{\circledR}$ (DIECKMANN, 1995; SILVA-NETO, 2000), with a cost

FIGURE 2: Photomicrographs of protists and rotifers after slide preparation. A: macroscopic view of the slide, (B - Q) microscopic views: B - Amoeba sp.; C - Difflugia sp.; D - Quadrulella sp.; E - Euplotes sp.; F - Vorticella sp.; G - Paramecium sp.; $\mathrm{H}$ - Peridinium sp.; I - Euglena sp.; J - Phacus sp.; K - Trachelomonas sp.; L - Lecane sp.; M - Plationus sp.; $\mathrm{N}$ - Brachionus sp.; O - Anabaena sp.; P - Pediastrum sp.; Q - cyst of Entamoeba sp. Images: B, C, E, F, L, M and N stained with rose bengal; D, G, H, I, J, K, O and P without dye; Q stained with lugol. Scales: Black bar = $100 \mu \mathrm{m}$; Blue bar: $50 \mu \mathrm{m}$.
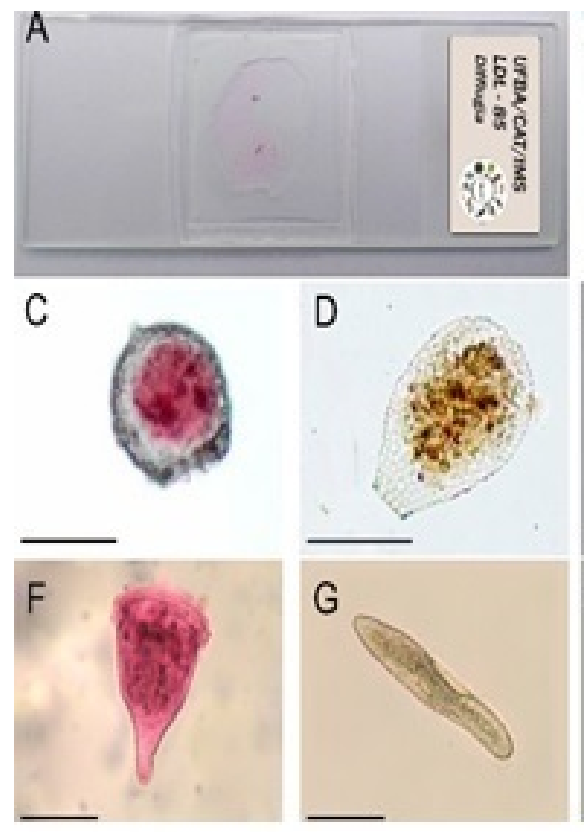

(1)
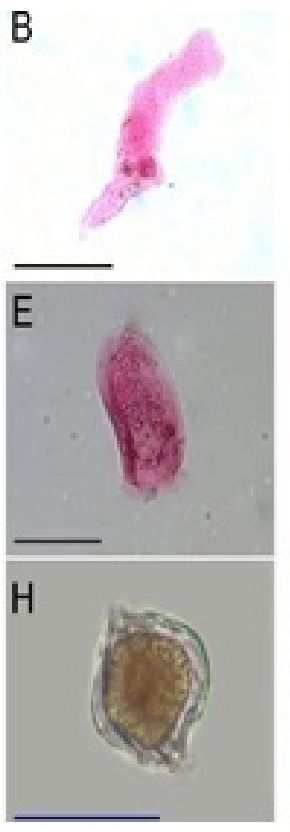
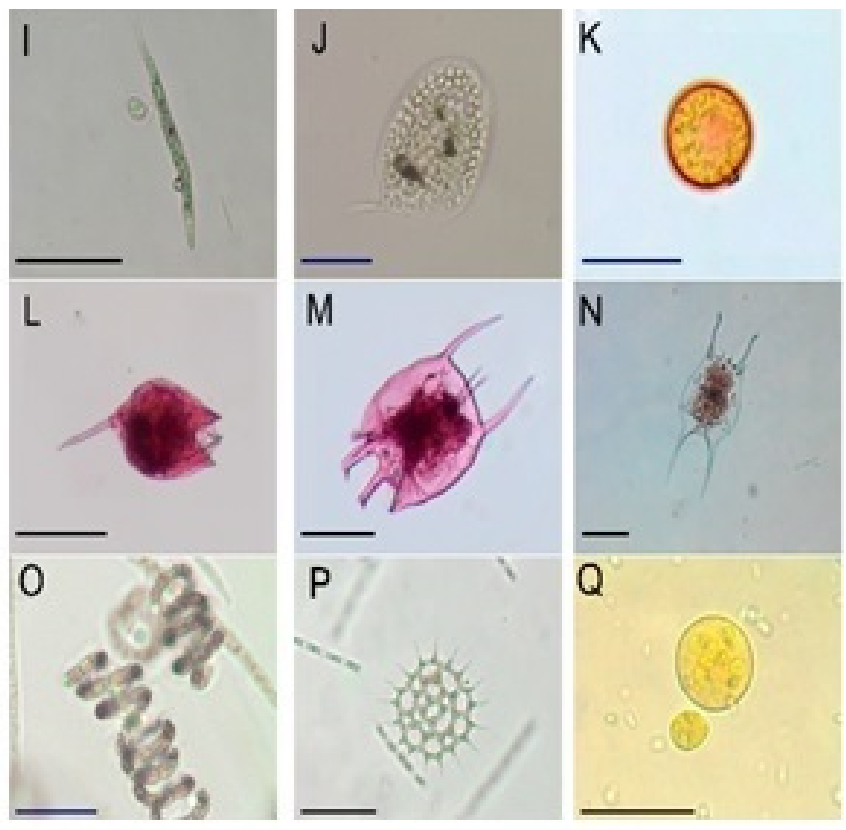
of $\mathrm{R} \$ 200.00$ per $100 \mathrm{~mL}$ of this substance, in addition to the extra costs of other reagents.

None of the slides presented crystallized reagents and signs of fungal contamination due to the antifungal effect promoted by phenol (HOLANDA et al., 2018). In time, since this substance is highly toxic and carcinogenic, we replaced its use with thymol, which is antifungal and antibacterial, and has a lower degree of toxicity (PINA-VAZ et al., 2004; ŠEGVIĆ-KLARIĆ et al., 2007).

As for the bubbles, these could occur if the temperature used in the heating plate is high during the melting of the gelatin. Therefore, placing the slide with the gelatin cube in heating at $60^{\circ} \mathrm{C}$ is recommended, though gradually; that is, placing and removing it from the heat and monitoring the melting, since glass is a poor conductor of heat, which can generate unnecessary overheating, the melting of gelatin and the formation of bubbles.

In the sealing phase, enamel, vitral varnish and Entellan ${ }^{\circledR}$ resin were tested. In the first two, medium leakage and dryness occurred over time. With Entellan ${ }^{\circledR}$, though there was greater efficiency, the costs were higher. Finally, we used the sealing technique proposed by Perina and Camacho (2016) for microcrustaceans, with adaptations: the results were more efficient and less costly with the use of paraffin and stained-glass layers.

During the experiment, we also observed that the mounting medium contained in the slides overflowed at high temperatures $\left(35^{\circ} \mathrm{C}\right)$, due to the low melting point of glyceryn-jelly $\left(25\right.$ to $\left.35^{\circ} \mathrm{C}\right)$ and the fact that gelatin forms thermoreversible gels. This problem was solved by storing the slides in a horizontal position in an environment with a controlled temperature of around $20^{\circ} \mathrm{C}$.

We must reiterate that this technique has been widely used in our slide preparations; until the present moment, no morphological alterations, fungi, bubble formation or deterioration in the slides have been observed. Furthermore, since its use has been recommended for years in Palynology, and recently used for the conservation of parasitic eggs (KUMAGAI et al., 2010) and sandflies (HOLANDA et al., 2018), its efficiency has been proven. Hence, the use of the technique proposed here is a viable alternative, with low risk of manipulation, low cost, as well as being simple, with the use of few reagents, to guide teachers and educational institutions in creating teaching materials that can enhance their practical classes with representative specimens of these microorganisms.

\section{Acknowledgments}

We are grateful to the Laboratory of Vegetable Micromorphology (LAMIV) of the State University of Feira de Santana (UEFS), for the guidelines in this adaptation and to Prof. Dr. Rodrigo Sussmann of the Federal University of the South of Bahia (UFSB) for the suggestions.

\section{References}

DIECKMANN, J. An improved protargol impregnation for ciliates yielding reproducible results. European Journal of Protistology, Stuttgart, v. 31, p. 372-382, 1995.

HOLANDA, V. G.; BARBOSA, D. B. S.; PEREIRA, L. A.; SOARES, M. R. A. Use of Kisser glycerol gelatin to prepare microscope slides of Phlebotomine sandflies (Diptera: Psychodidae). Revista da Sociedade Brasileira de Medicina Tropical, Uberaba, v. 52, p. 1-3, 2018.

JERSABECK, C. D.; BOLORTSETSEG, E.; TAYLOR, H. L. Mongolian rotifers on microscope slides: instructions to permanent specimen mounts from expedition material. Mongolian Journal of Biological Sciences, Ulaanbaatar, v. 8, n. 1, p. 51-57, 2010.

KUMAGAI, M.; INABA, T.; MAKIOKA, A.; ISHIWATA, K.; ONISHI, K.; WATANABE, N. An improved glycerin-jelly mounting procedure for permanent preparations of helminth eggs. Journal of Parasitology, Lawrence, v. 96, n. 2, p. 440-441, 2010.

PERINA, G.; CAMACHO, A. I. Permanent slides for morphological studies of small crustaceans: Serban's method and its variation applied on Bathynellacea (Malacostraca). Crustaceana, Leiden, v. 89, n. 10, p. 1161-1173, 2016.

PINA-VAZ, C.; GONÇALVES RODRIGUES, A.; PINTO, E.; COSTA-DE-OLIVEIRA, S.; TAVARES, C.; SALGUEIRO, L.; CAVALEIRO, C.; GONÇALVES, M.J.; MARTINEZ-DEOLIVEIRA, J. Antifungal activity of Thymus oils and their major compounds. European Academy of Dermatology and Venereology, Lugano, v. 18, n. 1, p. 73-8, 2014.

SALGADO-LABOURIAU, M. L. Palinologia: fundamentos, técnicas e algumas perspectivas. Revista Brasileira de Geografia, Rio de Janeiro, v. 23, n. 4, p. 695-717,1961. 
SEGVIĆ-KLARIĆ, M.; KOSALEC, I.; MASTELIĆ, J.; PIECKOVÁ, E.; PEPELJNAK, S. Antifungal activity of thyme (Thymus vulgaris $L$.) essential oil and thymol against moulds from damp dwellings. Letters in Applied Microbiology, Malden, v. 44, n. 1, p. 36-42, 2017.
SILVA-NETO, I. D. Improvement of silver impregnation technique (Protargol) to obtain morphological features of protists ciliates, flagellates and opalinates. Revista Brasileira de Biologia, São Carlos, v. 60, n. 3, p. 451-459, 2000. 